\title{
Performance of waste glass powder (WGP) supplementary cementitious material (SCM) - Workability and compressive strength
}

\author{
AdorJÁN BOROSNYÓI - Assoc. Prof., BME, Budapest, Hungary - adorjan.borosnyoi@gmail.com \\ PATRICIJA KARA - Scientific researcher, RTU, Riga, Latvia patricija.kara@rtu.Iv \\ LILLA MLINÁRIK - PhD candidate, BME, Budapest, Hungary - lilla.mlinarik@gmail.com \\ KARINA KAŠE - BSc candidate, RTU, Riga, Latvia - kash.karina@gmail.com
}

Érkezett: 2013. 11. 12. - Received: 12. 11. 2013. - http://dx.doi.org/10.14382/epitoanyag-jsbcm.2013.17

\begin{abstract}
Ecological and environmental benefits support the use of waste glass powder (WGP) as supplementary cementing material by the decrease of the amount of landfills, by the reduction of non-renewable natural resource consumption, by the reduction of energy demand for cement production (less cement is needed), and the reduction of greenhouse gas emission. Laboratory tests were carried out on cement paste specimens, in which waste glass powder (WGP) addition was used as a supplementary cementitious material. Cement was substituted with WPG at levels of $20 \%$ or $30 \%$ per mass. It was demonstrated that the WGP addition improves the workability of fresh pastes, and can be effectively used as cement replacement for compressive strength. It was also demonstrated that the particle size of the WGPs (specific surface area) has a stronger influence on the effectiveness of the cement replacement than the chemical composition. The effectiveness of the cement replacement increases as the specific surface area increases.

Keywords: recycling, waste glass, supplementary cementitious material, workability, compressive strength
\end{abstract}

\section{Introduction}

It is a challenge in civil engineering to transform the industrial wastes into construction material components. The increasing amount of unmanaged wastes has resulted in a critical environmental impact. The recycling of industrial wastes and the use of them as construction materials can provide a promising solution from both economy and ecology point of view, by the decrease of pollution and by the more economic design and architecture. Environmentally friendly and low-cost construction materials receive increasing attention recently, due to their attractiveness as building materials benefiting to the environment and promoting sustainability in the building construction industry.

Concrete is the most commonly used construction material in the planet and it is the second most consumed product after water [1].

As of 2012, the annual global cement production is over 3.6 billion tons, and is expected to be increased soon to over 4 billion tons per year, nevertheless, the cement industry is confronting with the continuous increase in cost for energy supplies, the obligations to reduce $\mathrm{CO}_{2}$ emission and the need of appropriate supply of raw materials both in quality and quantity $[2,3]$. It is estimated that about $0.9-1.0$ tons of $\mathrm{CO}_{2}$ are produced for a ton of clinker depending on the type of fuels used [4].

Nowadays, the clinker content of cements is intensively replaced by supplementary cementitious materials. Fly ash, blast furnace slag, natural pozzolans and limestone are used in increasing amounts that can substitute some clinker in the cement. Fig. 1 illustrates how the proportions of OPC
Adorján BOROSNYÓI

Civil engineer (MSC), PhD, Associate Professor at BME Dept. of Construction Materials and Engineering Geology. Main fields of interest: cracking and deflection of reinforced concrete, application of non-metallic (FRP) reinforcements for concrete structures, bond in concrete, nondestructive testing of concrete, supplementary cementing materials for high performance concretes, concrete technology. Secretary of the fib Task Group 4.1 "Serviceability Models" and Chairman of the SZTE Concrete Division.

Patricija KARA

Civil engineer (MSc), PhD candidate, Scientific researcher, Lecturer at Riga Technical University (RTU), Institute of Materials and Structures (IMS), Department of Building Materials and Products. RILEM Affiliate Member, TC 219-ACS and TC 225-SAP. Member of LVS STK 30 Eurocode SubCommittee. Main research area: concrete technology, waste glass recycling, recycling of industrial wastes and by-products in concrete, environmental management, eco-construction materials.

Lilla MLINÁRIK Chemical engineer (MSc), PhD student at BME Dept. of Construction Materials and Engineering Geology. Graduated at the Department of Physical Chemistry and Materials Science, of the Budapest University of Technology and Economics. Main fields of interest: $X$-ray and thermogravimetric analysis of inorganic materials, supplementary cementing materials on the chemical resistance of cements.

Karina KAŠE BSc student at Riga Technical University (RTU). BSc thesis theme: Investigation of cement paste properties with cement partial replacement with waste glass powder

declined over time in relation to the cements with other major constituents [2]. As a result, an average specific $\mathrm{CO}_{2}$ emission per ton of cement today is $20 \%$ lower compared to the 1990 s.

Ecological and environmental benefits of the supplementary cementitious materials are 1) non-recycled waste is used rather than increase the amount of landfills, 2) the consumption of non-renewable natural resources is reduced,3) the energy needed forcement production is reduced, 4) the emission of greenhouse gases is reduced [5].

\section{Waste glass for supplementary cementitious material}

Soda-lime glass is the most widely used glass for both packaging and in the building construction, however, based on chemical composition, glass can be categorized into several other categories as well. Containers, float and sheet glass are mostly soda-lime glass and, as a consequence, industrial waste glass is composed over $80 \%$ by weight of soda-lime glass [6]. For soda-lime glass the typical composition is approximately: $70 \% \mathrm{SiO}_{2}, 13-17 \% \mathrm{Na}_{2} \mathrm{O}$ and $10 \% \mathrm{CaO}$.

The characteristics of soda-lime glass make it suitable for consideration as an aggregate to concrete or as a supplementary cementitious material (SCM), but the high alkali content of soda-lime glass is one typical concern for the use in concrete. The possible formation of the harmful alkali-silica reaction (ASR) in contact with Portland cement may limit the 

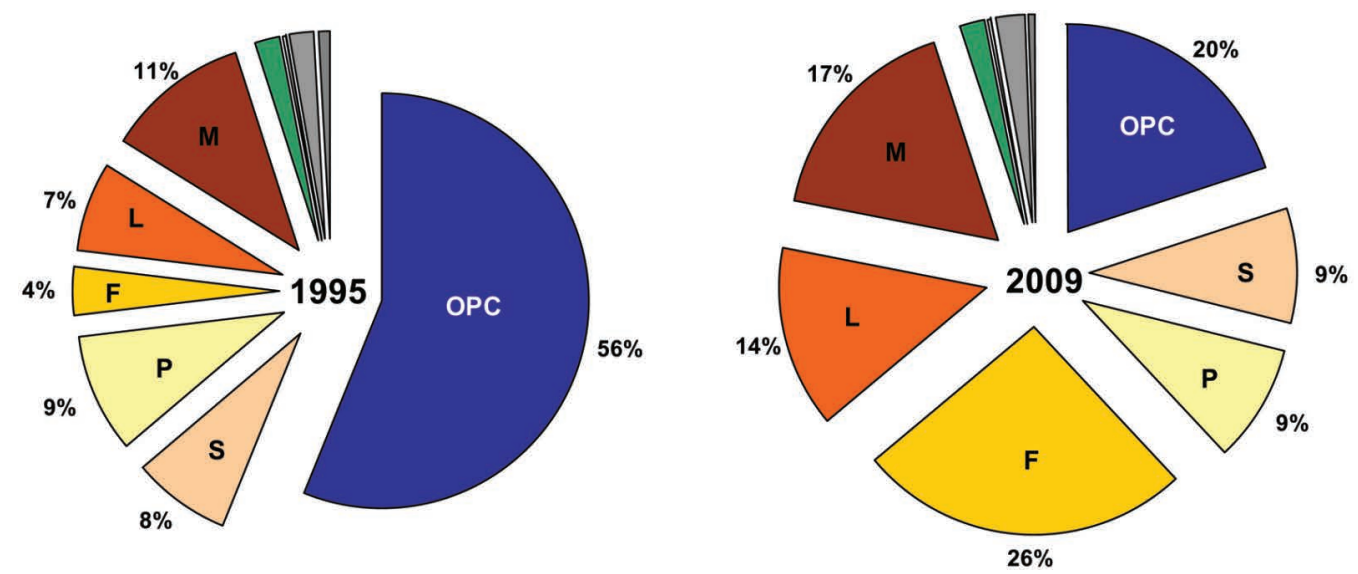

\begin{tabular}{|l|}
\hline$\square$ OPC \\
$\square$ S Slag Cement \\
$\square$ P Pozzolan Cement \\
$\square$ F Fly Ash Cement \\
$\square$ L Limestone Cement \\
$\square$ M Multiple Blend Cement \\
$\square$ Other Cem. Materials \\
$\square$ Masonry Cement \\
$\square$ Oilwell Cement \\
$\square$ White Cement \\
$\square$ Special Binder
\end{tabular}

Fig. 1. Proportions of supplementary materials in cements [2]

1. ábra Cement kiegészító anyagok alkalmazott mennyiségének változása [2]

applications. Alkalis can cause alkali-aggregate reaction and expansion if the aggregate of the concrete is reactive.

Experimental results have demonstrated that both particle size and glass colour have an influence on the expansion during alkali-silica reaction [7]. Generally, the finer glass particles exhibit considerably lower expansion; pozzolanic activity increases as fineness increases. Fine particles of waste glass powder (WGP) also tend to perform a relatively rapid pozzolanic reaction with Portland cement on the contrary to the much slower alkali-silica reaction. The combined use of other supplementary cementing materials such as fly ash, ground blast furnace slag and metakaolin can also decrease the expansion from ASR.

The pozzolanic properties of waste glass powder (WGP) are first notable at particle sizes below approximately $300 \mu \mathrm{m}$. Below $100 \mu \mathrm{m}$, glass can have a pozzolanic reactivity which is greater than that of fly ash. When ground to about the same fineness as Portland cement, waste glass powder (WGP) has advantageous pozzolanic behaviour: the amorphous silica $\left(\mathrm{SiO}_{2}\right)$ reacts with portlandite $\left(\mathrm{Ca}(\mathrm{OH})_{2}\right)$ generated during cement hydration to form gel of calcium silicate hydrate (CSH). No alkali-silica reaction was detected with particle size below $100 \mu \mathrm{m}$ [6].

It was found experimentally that $30 \%$ waste glass powder (WGP) could be incorporated as cement replacement in concrete without any long term disadvantageous effect [8].

Several studies have shown further beneficial effects, including increased workability and reduced permeability, of using WGP as a supplementary cementitious material (SCM), but the compressive strength is often lower when WGP is used as cement replacement, especially at early ages. Cement replacement with waste glass powder was shown to reduce early-age compressive strength, concrete mixtures with glass powder reached strength values close to the strength values for control mixtures at 28 days, and only one glass powder mixture reached a greater strength than the corresponding control at 91 days according to [9].

It was also shown that cement mortar with $20 \%$ waste glass powder replacement gained significant strength between 28 and 90 days showing pozzolanic reaction taking place in this period [10]. The continued strength development clearly indicates the beneficial pozzolanic reaction of the glass powder [11].
A reduction in the 28 days compressive strength of about $15 \%$ was observed when $20 \%$ of cement was replaced by waste glass powder $[10,12]$.

\section{Experimental studies}

Laboratory tests were carried out on cement paste specimens, in which wasteglass powder(WGP) addition was used as a supplementary cementitious material (SCM) during a cooperation research between the Budapest University of Technology and Economics (BME), Department of Construction Materials and Engineering Geology and the Riga Technical University (RTU), Institute of Materials and Structures (IMS), Department of Building Materials and Products..

\subsection{Materials}

For the specimens, CEM I $42.5 \mathrm{~N}$ Portland cement was used provided by a Hungarian cement manufacturer, with a specific surface area of $344 \mathrm{~m}^{2} / \mathrm{kg}$. The WGP addition materials were prepared in RTU IMS laboratory directly for the present experiments, using waste glass cullet collected in Latvia. Five different WGPs were studied. Fluorescent lamp tube glass waste cullet (LB) and incandescent light bulb borosilicate glass waste cullet (DRL) were received from a lamp recycling centre in Liepaja, Latvia. Container glass was obtained as bottles in green (G), amber (A) and flint (F) colours which were collected at a glass bottle return point in Riga, Latvia, and were manually crushed into cullet under laboratory conditions. The cullet was washed, dried and ground for 30 minutes in a laboratory planetary ball mill (Retsch PM400) with rotation speed 300 $\mathrm{min}^{-1}$. The specific surface area of the WGP was obtained by a Zwick/Roell ToniPERM automatic Blaine apparatus; further details of the WGP preparation are available in [13].

Earlier experiences have indicated that the five WGPs used in the present studies can serve as supplementary cementitious materials. It was demonstrated on concrete specimens [14] that WGP addition improves workability and results a softer consistency (demonstrated by standard slump tests), can contribute to the compressive strength of the hardened concrete and due to the relatively high specific surface area (maximum particle size was found to be smaller than $200 \mu \mathrm{m}$ in each case [13]) they have a relatively small influence on ASR expansion. 


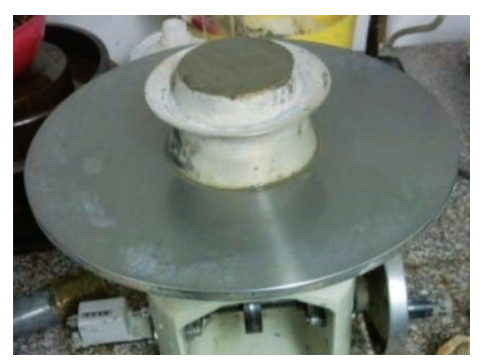

Fig. 2. Consistency tests according to EN 1015-3:1999 [16]

2. ábra Konzisztencia vizsgálata az EN 1015-3:1999 szerint [16]

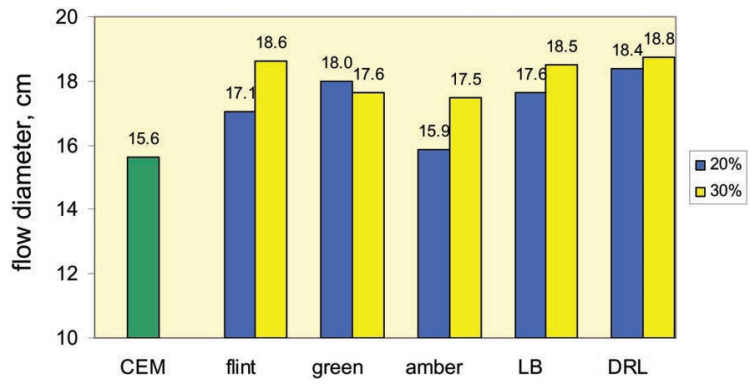

Fig. 3. Consistency tests results

3. ábra Konzisztencia vizsgálatok eredményei
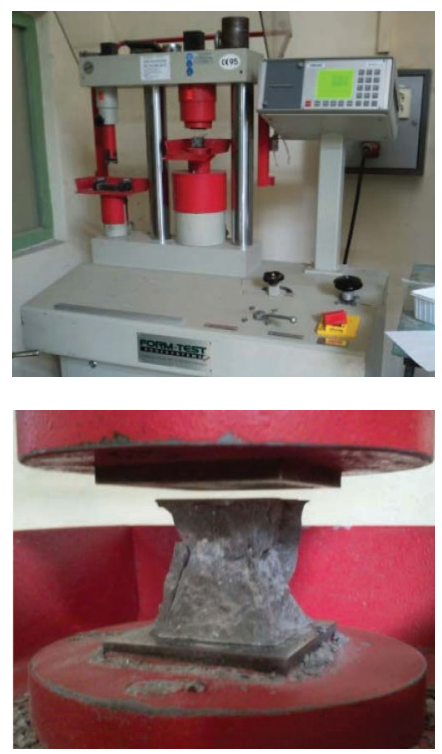

Fig. 4. Compressive strength tests according to EN 196-1:2005 [15]

4. ábra Nyomószilárdság vizsgálata az EN 196-1:2005 szerint [15]

The target of the present series of experiments was the direct analysis of the net influences of the WGPs on the hydration process of Portland cement, therefore, neat cement pastes were prepared with WGP addition. Cement was substituted with WPG at levels of $20 \%$ or $30 \%$ per mass of cement.

\subsection{Mixing and consistency}

The control cement paste mixture and the different paste mixtures with WGP addition were mixed in a laboratory mortar mixer according to EN 196-1:2005 [15]. The water/cement ratio was selected to be w/c $=0.285$. Where cement replacement by WGP was applied, the water/binder ratio was changed to $\mathrm{w} / \mathrm{b}=$ 0.342 (20\% WGP) and w/b = 0.3705 (30\% WGP), however, the water/cement ratio was kept constant at w/c=0.285.
The consistency was tested by a standard flow table (Fig. 2) according to EN 1015-3:1999 [16]. The flow table tests were repeated twice for each mixture. After the 15 drops of the flow table (one drop in 2 seconds) the final diameter of the sample was measured in two directions by a steel ruler. Flow table test results are indicated in Fig. 3. It can be seen that the WGP addition increases the flow of the fresh pastes. The higher is the amount of the WGP, the higher is the improvement in workability.

\subsection{Compressive strength}

For the compressive strength tests, $30 \mathrm{~mm}$ size cubic specimens were prepared in steel moulds. During the first 14 days of curing period specimens were kept in water in the climatic chamber, after 14th days half of specimens was stored in the climatic chamber (at temperature $20 \pm 2{ }^{\circ} \mathrm{C}$ and relative humidity $>65 \%$ ) and half of the specimens was kept continuously under water. Compressive strength of cement paste specimens was determined at the age 2, 7, 14, 28, 91, 147 and 302 days (Fig. 4) according to EN 196-1:2005 [15]. The evolution of the compressive strength of the specimens stored under water is indicated in Fig. 5. where the hardened neat cement paste is indicated with red colour.

\section{Discussion of strength results}

The development of the compressive strength is indicated in separate diagrams for the five GWPs in comparison to the neat cement paste (see Fig. 6.a, 7.a, 8.a, 9.a, 10.a). Strength development of the hardened neat cement paste at the age of $t$ days, is indicated with red colour in each diagram. It can be generally concluded that the cement replacement by GWP was successful form a compressive strength point of view and no significant reduction of the compressive strength can be realised, especially for the mature specimens.

The effectiveness of the cement replacement can be characterised morepreciselyiftherelative development of the compressive strength is studied. Fig. 6.b, 7.b, 8.b, 9.b, 10.b indicate the relative compressive strength values corresponding to the different WGPs. The level of 1.0 indicates the compressive strength of the hardened neat cement paste at the age of $t$ days, as a reference level in each diagram (indicated with red colour). It can be seen that the compressive strength of the pastes containing WGP addition reaches that of the reference hardened neat cement paste at the age of 28 to 91 days, according to the present laboratory tests. The significance of the WGP amount is also visible: usually, the $20 \%$ replacement resulted higher compressive strength values than the 30\% replacement. It seems that only a part of the WGP can be activated by ordinary Portland cement during the period of the present experiments ( $\sim$ one year). A rapid development of the compressive strength is visible between the ages of 28 to 91 days, being faster than that of the hardened neat cement paste that is attributed to a supposed very active hydration of the WGPs during that period of time. At later ages the relative rate of hydration is balanced between the cement and the WGPs, resulted in a decelerated rate and a constant difference in compressive strength values.

It can be also demonstrated that the particle size of the WGPs has a stronger influence on the effectiveness of the cement replacement than e.g. the chemical composition. Fig. 11 indicates 
the relative compressive strength values corresponding to the age of 302 days over the specific surface area of the WGPs used in the present experiments, according to [13]. The effectiveness of the cement replacement increases as the specific surface area increases. The flint WGP seems to be an outlier during the present tests. The results further confirm the importance of the preparation of WGPs with high specific surface area for the optimal supplementary cementitious material performance.

\section{Conclusions}

The present paper has summarised the experimental results of a laboratory test series carried out on cement paste specimens, in which waste glass powder (WGP) addition was used as a supplementary cementitious material (SCM) during a cooperation research between the Budapest University of Technology and Economics (BME), Department of Construction Materials and Engineering Geology and the Riga Technical University (RTU), Institute of Materials and Structures (IMS). CEM I $42.5 \mathrm{~N}$ Portland cement was used with WPG substitution at levels of $20 \%$ or $30 \%$ per mass of cement.

It was demonstrated that the WGP addition:

- improves the workability of fresh pastes,

- can be effectively used as cement replacement for compressive strength.

It was demonstrated that the particle size of the WGPs (specific surface area) has a stronger influence on the effectiveness of the cement replacement than the chemical composition.

\section{Acknowledgement}

Authors gratefully acknowledge the support of the Hungarian Scientific Research Fund project "Durability and performance characteristics of concretes with novel type supplementary materials" (OTKA K 109233).

\section{References}

[1] Mehta, P. K. - Monteiro, P. J. M.: Concrete: microstructure, properties, and materials. McGraw-Hill, 659 p. (2006)

[2] Schneider, M. - Romer, M. - Tschudin, M. - Bolio, H.: Sustainable cement production - present and future. Cement and Concrete Research Vol. 41, No. 7, July 2011, pp. 642-650. http://dx.doi.org/10.1016/j.cemconres.2011.03.019

[3] Cembureau: The role of cement in the 2050 low carbon economy. The European Cement Association. (2013). http://lowcarboneconomy.cembureau.eu

[4] Cembureau: Sustainable cement production: Co-processing of alternative fuels and raw materials in the cement industry. The European Cement Association. (2009). http://www.cembureau.be

[5] Federico, L. M. - Chidiac, S. E.: Waste glass as a supplementary cementitious material in concrete - Critical review of treatment methods. Cement \& Concrete Composites, Vol. 31, No. 8, September 2009, pp. 606610. http://dx.doi.org/10.1016/j.cemconcomp.2009.02.001

[6] Corinaldesi, V. - Gnappi, G. - Moriconi, G. - Montenero, A.: Reuse of ground waste glass as aggregate for mortars. Waste Management, Vol. 25, No. 2, 2005, pp. 197-201. http://dx.doi.org/10.1016/j.wasman.2004.12.009

[7] Jin, W. - Meyer, C. - Baxter, S.: Glascrete - concrete with glass aggregate. ACI Materials Journal, Vol. 97, No. 2, pp. 208-213. (2000)

[8] Shayan, A. - Xu, A.: Performance of Glass Powder as a Pozzolanic Material: A Field Trial on Concrete Slabs. Cement and Concrete Research, Vol. 36, No. 3, March 2006, pp. 457-468. http://dx.doi.org/10.1016/j. cemconres.2005.12.012

[9] Tagnit-Hamou, A. - Bengougam, A.: The Use of Glass Powder as Supplementary Cementitious Material. Concrete International, Vol. 34, No. 3, March 2012, pp. 56-61.

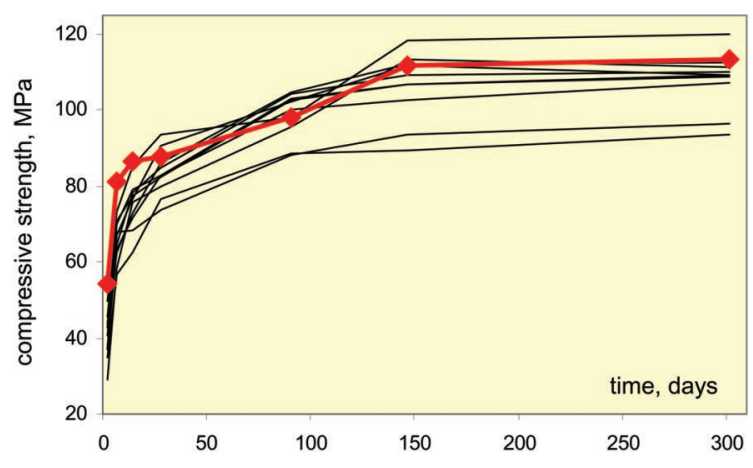

Fig. 5. Evolution of the compressive strength of the specimens stored under water 5. ábra Nyomószilárdság időbeli fejlödése a végig víz alatt tárolt mintákon
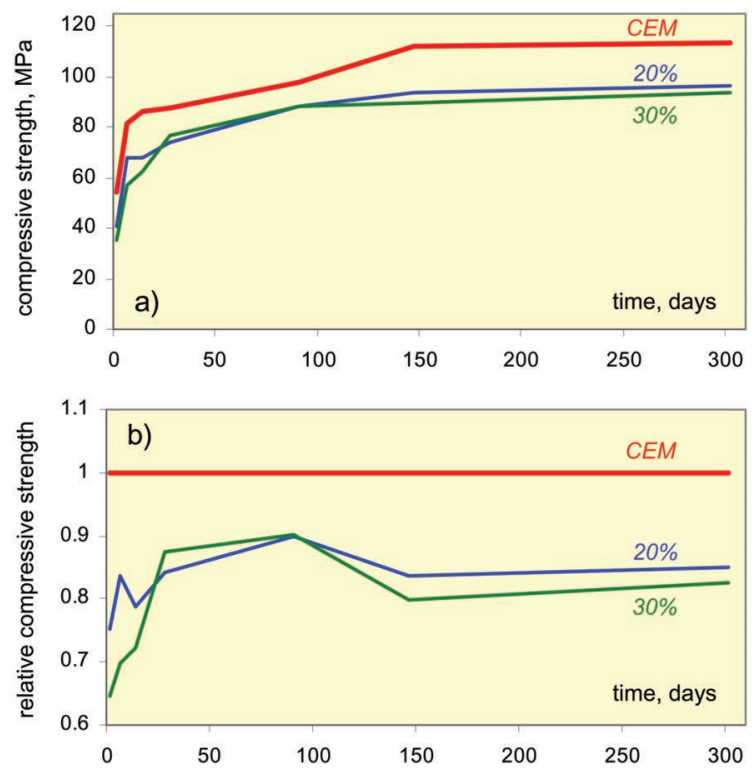

Fig. 6. Compressive strength and relative compressive strength of specimens with flint WGP

6. ábra Nyomószilárdság és relativ nyomószilárdság fejlődése a fehér szinü hulladék üveg por kiegészitövel
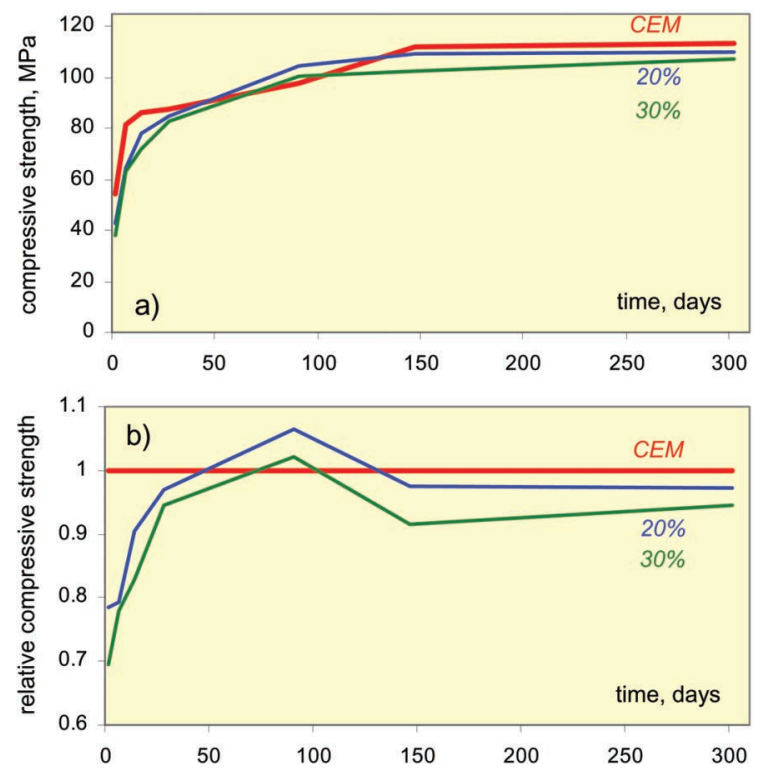

Fig. 7. Compressive strength and relative compressive strength of specimens with green $W G P$

7. ábra Nyomószilárdság és relatív nyomószilárdság fejlődése a zöld színü hulladék üveg por kiegészítővel 

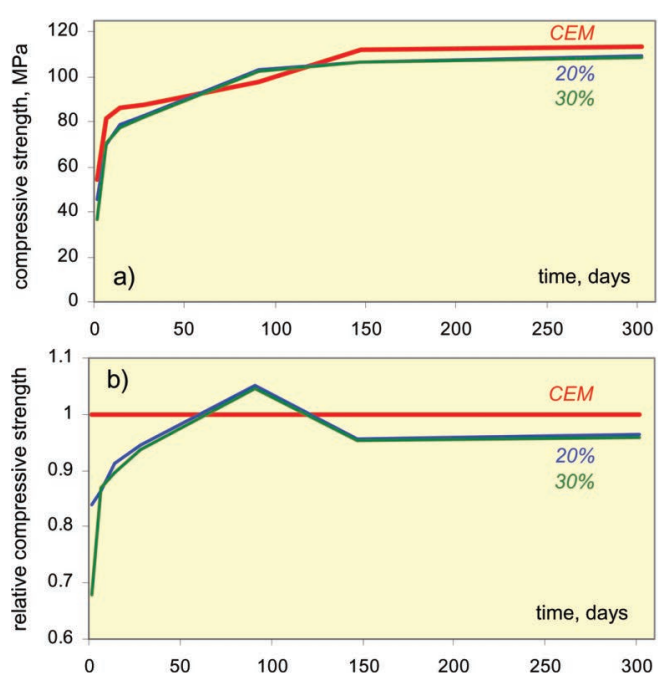

Fig. 8. Compressive strength and relative compressive strength of specimens with amber WGP

8. ábra Nyomószilárdság és relatív nyomószilárdság fejlődése a borostyán színü hulladék üveg por kiegészitővel
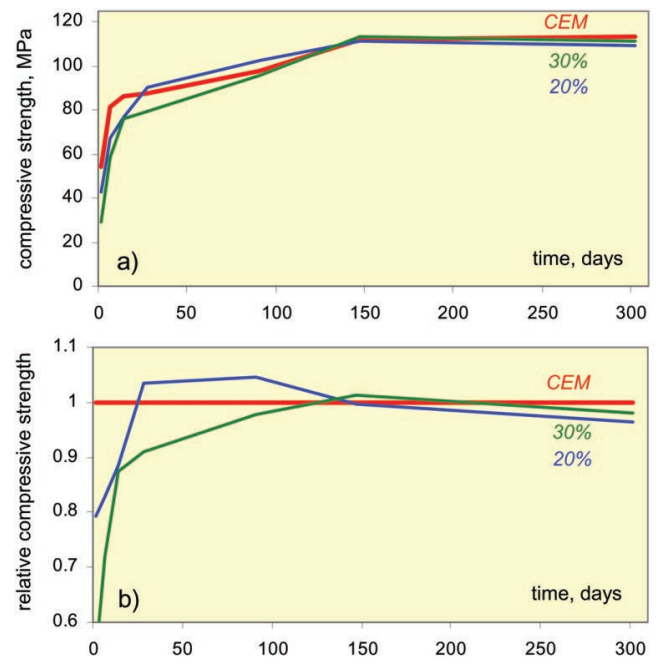

Fig. 9. Compressive strength and relative compressive strength of specimens with $L B W G P$ 9. ábra Nyomószilárdság és relatív nyomószilárdság fejlődése a fénycső hulladék üveg por kiegészítővel
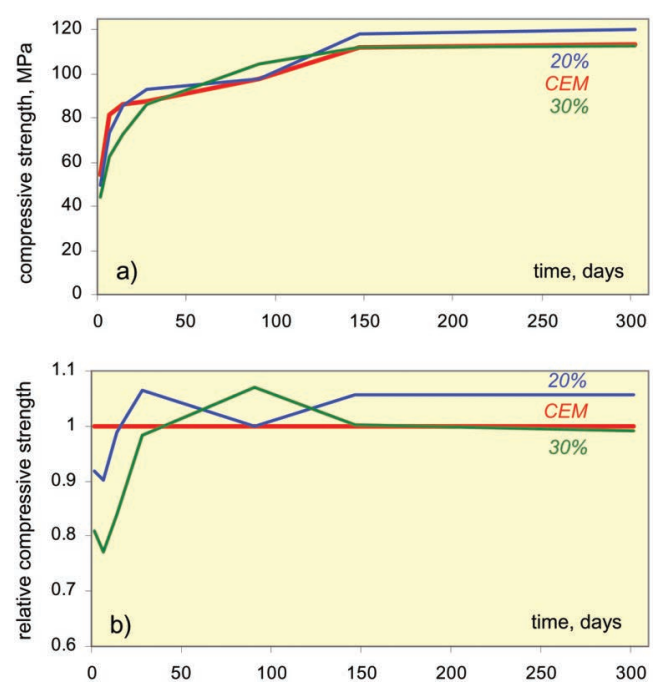

Fig. 10. Compressive strength and relative compressive strength of specimens with DRL WGP 10. ábra Nyomószilárdság és relatív nyomószilárdság fejlődése a villanykörte hulladék üveg por kiegészítôvel

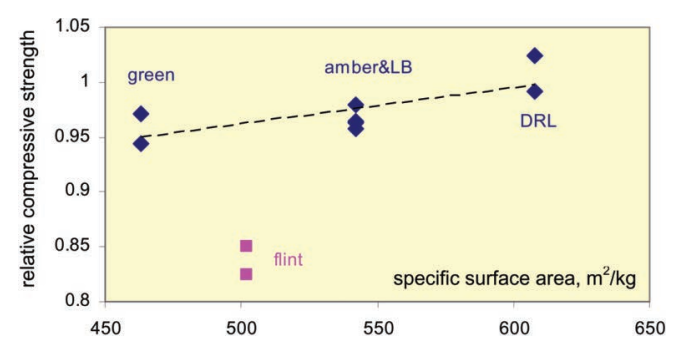

Fig. 11. Relative compressive strength vs. specific surface area of WGPs

11. ábra A relatív nyomószilárdság a hulladék üveg por kiegészitők fajlagos felületének függvényében

[10] Matos, A. M. - Sousa-Coutinho, J.: Durability of mortar using waste glass powder as cement replacement. Construction and Building Materials, Vol. 36, November 2012, pp. 205-215. http://dx.doi.org/10.1016/j. conbuildmat.2012.04.027

[11] Shayan, A.: Value-added utilization of waste glass in concrete. Cement and Concrete Research, Vol. 34, No. 1, January 2004, pp. 81-89. http://dx.doi. org/10.1016/S0008-8846(03)00251-5

[12] Taha, B. - Nounou, G.: Properties of concrete contains mixed colour waste recycled glass as sand and cement replacement. Construction and Building Materials, Vol. 22, No. 5, May 2008, pp. 713-720. http://dx.doi. org/10.1016/j.conbuildmat.2007.01.019

[13] Kara, P.: The Influence of Waste Glass Slurry on the Properties of Concrete. International Journal of Application or Innovation in Engineering \& Management (IJAIEM), Vol. 2, No. 8, August 2013, pp. 325-330.

[14] Kara, P. - Korjakins, A. - Kovalenko, K.: The Usage of Fluorescent Waste Glass Powder in Concrete. Construction Science, Vol. 13, November 2012, pp. 26-32. http://dx.doi.org/10.2478/v10311-012-0004-z

[15] CEN: EN 196-1:2005, Methods of testing cement - Part 1: Determination of strength. European Standard, CEN/TC 51 - Cement and building limes, 2005-08-31 (2005)

[16] CEN: EN 1015-3:1999, Methods of test for mortar for masonry - Part 3: Determination of consistence of fresh mortar (by flow table). European Standard, CEN/TC 51 - Cement and building limes, 1999-08-31 (1999)

$\underline{\text { Ref.: }}$

Adorján Borosnyói - Patricija Kara - Lilla Mlinárik - Karina

Kaše: Performance of waste glass powder (WGP) supplementary cementitious material (SCM) - Workability and compressive strength Építőanyag, 65. évf. 3. szám (2013), 90-94. p.

http://dx.doi.org/10.14382/epitoanyag-jsbcm.2013.17

\section{Megőrölt hulladék üveg (WGP) cement kiegészítő anyag (SCM) tulajdonságai - Bedolgozhatóság és nyomószilárdság vizsgálata}

A megốrölt hulladék üveg cement kiegészítô anyagként történố felhasználása gazdasági és ökológiai haszonnal is jár: csökkenthetố a hulladékdepóniákban elhelyezett anyag mennyisége, csökkenthetô a nem megújuló nyersanyag felhasználás mértéke, csökkenthetố a cementgyártás energiaigénye (kevesebb cement gyártása szükséges), csökkenthetô ez által az üvegházhatást okozó gázok kibocsátásának mennyisége. Egy laboratóriumi vizsgálatsorozat keretein belül megörölt hulladék üveget alkalmaztunk cement kiegészítô anyagként. A kiegészítô anyag mennyiség 20\% és 30\% volt a cement tömegére vonatkoztatva. Kimutattuk, hogy a megốrölt hulladék üveg cement kiegészítô anyag javítja a cementpép bedolgozhatóságát és közremúködik a megszilárdult pép nyomószilárdságában. Megfigyeltük, hogy a megórölt hulladék üveg fajlagos felületének nagyobb szerepe van a kiegészítô anyagként történô hatékony múködésben, mint a kémiai összetételének.

Kulcsszavak: újrahasznosítás, hulladék üveg, cement kiegészítô anyag, bedolgozhatóság, nyomószilárdság 